\title{
The Possible Underworld of Chronic Fatigue Syndrome From Neurotransmitters Polymorphisms to Disease
}

\author{
Sara Bozzinia, Chiara Boiocchi ${ }^{b}$, Nicoletta Carlo-Stella ${ }^{a}$, \\ Giovanni Ricevutic ${ }^{\text {, Mariaclara Cuccia }}{ }^{\mathrm{a}, \mathrm{d}}$
}

\begin{abstract}
Background: Chronic fatigue syndrome is a complex and debilitating disorder. Several clinical studies suggest dysregulation of the hypothalamic-pituitary-adrenal axis and perturbations of the immune and central nervous systems. In this study we esamined the association between serotonin transporter (SERT) and receptor 2A (HTR2A), Glycogen synthase kinase 3 beta (GSK3B) and Brain Derived Neurotrophic Factor (BDNF) genes polymorphisms and $\mathrm{CFS}$, in order to describe genetic associations.
\end{abstract}

Methods: The coding and untranslated regions of each gene examined were analyzed by PCR-RFLP.

Results: The $44 \%$ of the CFS patients presents depressive symptoms: in this subgroup the presence of female sex is significantly higher $(88 \%)$ than in not depressed patients $(35 \%)(\mathrm{P}=0.0002)$. The genotypic and allelic frequencies of the HTR2A $-1438 \mathrm{G} / \mathrm{A}$ polymorphism showed a statistically significant difference $(\mathrm{P}=$ 0.05): the AA genotype is more present in patients with depressive symptoms. In particular, the frequency of the AA genotype was higher in the depressed patients $(48 \%)$ compared to the patients without depressive symptoms $(21 \%)$. The crude odds ratio for the

Manuscript accepted for publication February 21, 2012

${ }^{\mathrm{a}}$ Genetics and Microbiology Department, University of Pavia, Pavia, Italy

${ }^{\mathrm{b}}$ Department of neurological Sience, IRCCS National Neurological Institute "C. Mondino", university of Pavia, Pavia, Italy

${ }^{c}$ Department of Internal Medicine and Therapeutics, Geriatric Section,

University of Pavia, IDR S. Margherita, Pavia, Italy

${ }^{\mathrm{d}}$ Corresponding author: Mariaclara Cuccia.

Email: mariaclara.cuccia@unipv.it

doi:10.4021/jnr86w presence of CFS associated with depression in subjects bearing the homozygous AA genotype was 3.56 (95\% CI, 1.13 - 11.17).

Conclusions: References of increased promoter activity, mRNA, protein levels and receptor binding with this promoter polymorphism and the association of the A allele with CFS sustain a hyperactive serotonergic system in this disease. So we suppose that the neuroendocrine system remains an intriguing field of research in CFS.

Keywords: Chronic fatigue syndrome; Neuroendocrinological theory; Serotonin; Glycogen synthase kinase 3; Brain derived neurotrophic factor; Depression

\section{Introduction}

The chronic fatigue syndrome (CFS) is characterized by intense fatigue of unknown cause, which is permanent and limits the patient's functional capacity, producing degrees of disability [1]. The pathophysiology is unknown to date; cytokines, neuropeptides, or neurotransmitters are considered to be responsible for the abnormal immune response and disrupted hypothalamo-pituitary-adrenal (HPA) axis found in patients $[2,3]$. An increasing amount of neuroimaging evidence supports the hypothesis that CFS patients have a sort of neurological, structural or functional abnormalities. Moreover, neurotrophic factors, neurotransmitters and cytokines have been evaluated in order to elucidate possible mechanisms of abnormal neuropsychic findings in thus syndrome $[4,5]$.

The major neurotransmitters involved in descending pain-modulating systems are norepinephrine and serotonin. The serotonin transporter (SERT) is an integral membrane protein that transports serotonin from synaptic spaces into presynaptic neurons, terminates the action of serotonin and recycles it in a sodium-dependent manner. The gene encoding for SERT is called SLC6A4 and it is located on chromosome 17 (q11.1-q12). The promoter region of the SLC6A4 gene contains a polymorphism with "short" and "long" repeats in the 5-HTT-linked polymorphic region (5-HTTLPR, 
Table 1. Primer Pairs and Restriction Enzyme Used for Genetic Analysis

\begin{tabular}{|c|c|c|c|c|}
\hline Polymorphism & Primer Sequence & Annealing & $\begin{array}{l}\text { Amplified } \\
\text { Fragment } \\
\text { Size (bp) }\end{array}$ & $\begin{array}{l}\text { Restriction } \\
\text { Enzyme }\end{array}$ \\
\hline SLC6A4 5HTLPR & $\begin{array}{l}\text { GGCGTTGCCGCTCTGAATGC } \\
\text { GAGGGACTGAGCTGGACAACCAC }\end{array}$ & $61{ }^{\circ} \mathrm{C}$ & $\begin{array}{l}484 \text { (S allele) } \\
528 \text { (L allele) } \\
613 \text { (XL allele) }\end{array}$ & \\
\hline HTR2A -1438 G/A & $\begin{array}{l}\text { AAGCTGCAACCTAGCAACAGC } \\
\text { AACCAACTTATTTCCTACCAC }\end{array}$ & $60^{\circ} \mathrm{C}$ & 468 & HpaII \\
\hline BDNF Val66Met & $\begin{array}{l}\text { AGAAGAGGAGGCTCCAAAGG } \\
\text { CTGATTTGTGTCTGGTGCAG }\end{array}$ & $60^{\circ} \mathrm{C}$ & 499 & PmlI \\
\hline GSK3B $-50 \mathrm{~T} / \mathrm{C}$ & $\begin{array}{l}\text { CTCGCTTCCTTCCTTCCTTT } \\
\text { GATTCCCAGACGCCTGTTAC }\end{array}$ & $58^{\circ} \mathrm{C}$ & 237 & AluI \\
\hline GSK3B -157 T/C & $\begin{array}{l}\text { CAGCTGCTTTGCACTAACAGA } \\
\text { TTAGGTGACAAACGCTTTCTTT }\end{array}$ & $55^{\circ} \mathrm{C}$ & 250 & Hpy188I \\
\hline
\end{tabular}

rs25531). The short variation leads to less transcription for SLC6A4, and it has been found that it can partly account for anxiety-related personality traits [6]. The serotonin receptors $2 \mathrm{~A}$ is coded by the HTR2A gene located on 13q14-q21. This receptor is expressed widely throughout the central nervous system where it mediates neuronal excitation, behavioral effects, learning, anxiety. Several interesting polymorphisms have been identified for HTR2A; in particular, several studies shown links between the -1438G/A (rs6311) polymorphism and mood disorders, such as bipolar disorder [7] and major depressive disorder [8].

Deficits in neurotrophic factors have been proposed to underlie mood disorders: neurotrophins may act as critical tools in the process whereby environmental conditions guide neuronal networks to better adapt to the environment [9]. Brain derived neurotrophic factor has pleiotropic effects on neuronal development and synaptic plasticity that underlie circuit formation and cognitive function [10]. It is encoded by the BDNF gene located on chromosome 11. The Val66Met (rs6265) single nucleotide polymorphism results in a variation in the protein between Valine and Methionine at codon 66 [11].

Glycogen synthase kinase 3 (GSK3) is involved in a variety of cellular processes ranging from glycogen metabolism, insulin signaling, cell proliferation, neuronal function, oncogenesis to embryonic development. GSK3 is ubiquitously expressed with high levels in brain and is associated with a variety of neurological disease like Alzheimer's, bipolar disorder, Huntington disease and other neurodegenerative disorders $[12,13]$. In the GSK3B gene, located on chromo- some 3q13.3, are described two functional SNPs: a promoter polymorphism (rs334558) and a polymorphism in intron 5 (rs6438552) [14].

Thus, we provide an association study between the SLC6A4, HTR2A and GSK3B gene polymorphisms and CFS in Italian population.

\section{Materials and Methods}

\section{Experimental subjects}

The patients were recruited through three Italian referral Centers for CFS (Oncological Referring Center-Aviano, Prof. U. Tirelli; Department of Infectious Diseases, University of Chieti, Prof. E. Pizzigallo; Department of Rheumatology, University of Pisa, Dr. L. Bazzichi) and were enrolled only patients with a certified diagnosis of CFS. A questionnaire was used to re-confirm the diagnosis and exclude any other possible causes of fatigue by symptom referral, lab tests and personal/family histories of immune and hereditary disease. All patients are Italian in order to have a homogenous genetic background between patients and controls.

A biological bank of CFS patients was established in Pavia (Laboratory of Immunogenetics, Department of Genetics and Microbiology) containing peripheral blood, mRNA, serum and red blood cells as already described elsewhere [15].

A total of 128 healthy blood donors (49 males, 94 females), matched for age, sex and ethnical origins, served as controls. 
Table 2. Clinical Characteristics and Presence of XMRV of 70 Italian CFS Patients

\begin{tabular}{ll}
\hline Clinical Features & \% $(\mathbf{n}=\mathbf{7 0})$ \\
\hline Age of onset & $33.5 \pm 12.5$ \\
Male & $23 \%$ \\
Female & $77 \%$ \\
Arthralgia & $89 \%$ \\
Myalgia & $8 \%$ \\
Depressive symptoms & $43 \%$ \\
Unexplained fever & $60 \%$ \\
Comorbidities & \\
$\quad$ Type 2 Diabetes & $3 \%$ \\
Hypothyroidisms & $4 \%$ \\
Rheumatoid Arthritis & $1 \%$ \\
\hline
\end{tabular}

Approval for this study was obtained from the Ethics Committee of the University of Pavia. After a complete explanation of the aims and details of the study, written informed consent has been obtained from all the subjects.

\section{Genetic analysis}

Genomic DNA was extracted from EDTA-treated blood using the DNA Blood Mini Kit (Qiagen). All the SNP considered in this study were analyzed through PCR-RFLP method.

The coding and untranslated regions of each gene examined were amplified by PCR using the primers listed in Table 1. PCR amplifications were carried out in a total volume of $25 \mu$ containing: $20 \mathrm{ng}$ of genomic DNA; $0.1 \mu \mathrm{l}$ of Taq polymerase $(0.02 \mathrm{U} / \mu \mathrm{l}) ; 1 \mu \mathrm{l}$ of each specific primer forward and reverse $(4 \mathrm{ng} / \mu \mathrm{l}) ; 2.5 \mu \mathrm{l}$ PCR Buffer 10X; $0.75 \mu \mathrm{MgCl}_{2}(1.5$ $\mathrm{mM}) ; 2.5 \mu \mathrm{l}$ dNTPs (2 mM each); $16.15 \mu \mathrm{l}$ of sterile $\mathrm{H}_{2} \mathrm{O}$. Thirty-five amplification cycles were performed, consisting of denaturation at $95^{\circ} \mathrm{C}$ for 30 seconds, annealing, and elongation at $72^{\circ} \mathrm{C}$ for 1 minute (Table 1). An initial denaturation step was carried out at $95^{\circ} \mathrm{C}$ for 5 minutes, and final elongation at $72{ }^{\circ} \mathrm{C}$ for 7 minutes. The amplified segment was run on a $2 \%$ agarose gel and read using a U.V. transilluminator.

The amplified segments were digested using specific restriction enzyme (Table 1) repentantly for 4 hours at $37{ }^{\circ} \mathrm{C}$ and the digest run on a $3 \%$ agarose gel and read using a U.V. transilluminator.

\section{Statistical analyses}

A $\chi^{2}$ test for goodness of fit was used to verify whether the observed allele frequencies agreed with those expected under Hardy-Weinberg equilibrium. Allelic and genotypic distribution were estimated by $\chi^{2}$ test and differences considered statistically significant when the P-value was $<0.05$. Crude and adjusted odds ratios (ORs) are reported with their 95\% confidence intervals (CIs) using univariate analyses.

\section{Results}

We observed a bias towards female sex (3:1 ratio) in agreement with international literature [16-19]. The mean age at CFS onset \pm SD was $32.2 \pm 12.9$ and $33.9 \pm 12.5$ years for male and female patients $(\mathrm{P}=0.62)$, respectively (Table 2$)$. In any polymorphisms of SLC6A4, HTR2A, BDNF and GSK3B genes analyzed, the allelic and genotypic frequencies is not significant different in patients and controls (Table 3 ). Genotypes were in Hardy-Weinberg equilibrium both in the patients and controls. For the same polymorphisms in the CFS patients population, divided according to gender, no statistically significant data were found (Table 4).

Arthralgia was the main symptom among CFS patients (89\%). Noteworthy, statistical significant differences in frequencies for arthralgia were found between female (95\%) 
Table 3. Allelic and Genotypic Distribution Between CFS Patients and Controls

\begin{tabular}{|c|c|c|c|}
\hline & $\begin{array}{l}\text { CFS patients (n } \\
=70)\end{array}$ & $\begin{array}{l}\text { Controls } \\
(n=128)\end{array}$ & P value \\
\hline \multicolumn{4}{|c|}{ SLC6A4 5-HTTLPR } \\
\hline LL & $34 \%$ & $29 \%$ & ns \\
\hline LS & $47 \%$ & $53 \%$ & ns \\
\hline SS & $18 \%$ & $18 \%$ & ns \\
\hline $\mathrm{L}$ & $58 \%$ & $55 \%$ & ns \\
\hline S & $42 \%$ & $45 \%$ & ns \\
\hline \multicolumn{4}{|c|}{ HTR2A -1438 G/A } \\
\hline GG & $23 \%$ & $17 \%$ & $\mathrm{~ns}$ \\
\hline GA & $48 \%$ & $56 \%$ & ns \\
\hline AA & $29 \%$ & $17 \%$ & ns \\
\hline G & $47 \%$ & $50 \%$ & ns \\
\hline A & $53 \%$ & $50 \%$ & $\mathrm{~ns}$ \\
\hline \multicolumn{4}{|c|}{ BDNF Val66Met } \\
\hline GG & $50 \%$ & $51 \%$ & ns \\
\hline GA & $34 \%$ & $32 \%$ & ns \\
\hline AA & $11 \%$ & $17 \%$ & ns \\
\hline G & $64 \%$ & $67 \%$ & ns \\
\hline A & $36 \%$ & $33 \%$ & ns \\
\hline \multicolumn{4}{|c|}{ GSK3B $-50 \mathrm{~T} / \mathrm{C}$} \\
\hline TT & $46 \%$ & $39 \%$ & ns \\
\hline TC & $44 \%$ & $40 \%$ & $\mathrm{~ns}$ \\
\hline $\mathrm{CC}$ & $10 \%$ & $15 \%$ & ns \\
\hline $\mathrm{T}$ & $68 \%$ & $63 \%$ & ns \\
\hline $\mathrm{C}$ & $32 \%$ & $37 \%$ & ns \\
\hline \multicolumn{4}{|c|}{ GSK3B -157 T/C } \\
\hline TT & $63 \%$ & $46 \%$ & ns \\
\hline $\mathrm{TC}$ & $27 \%$ & $39 \%$ & ns \\
\hline $\mathrm{CC}$ & $10 \%$ & $15 \%$ & ns \\
\hline $\mathrm{T}$ & $76 \%$ & $66 \%$ & $\mathrm{~ns}$ \\
\hline $\mathrm{C}$ & $24 \%$ & $34 \%$ & $\mathrm{~ns}$ \\
\hline
\end{tabular}

and male $(77 \%)$ patients $(\mathrm{OR}=5.62,95 \% \mathrm{CI} 1.13-28.02)$. Clinical variables were not significantly different between gender. Myalgia had the lowest frequency among symptoms (8\%). Concerning comorbidities, $3 \%$ of patients had type 2 diabetes, $4 \%$ had hypothyroidism, one patient had Rheumatoid Arthritis (1\%), and in another patient (1\%) the diagnosis of psoriasis was confirmed. Data shown in Table 2.

The $43 \%$ of the CFS patients presents depressive symptoms (Table 2). In the subgroup of CFS patients with depressive symptoms the presence of female sex is significant higher (88\%) than in the not depressed patients $(35 \%)$. On the contrary, the presence of male gender is significant high- 
Table 4. Allelic and Genotypic Distribution Between Male and Female CFS Patients

\begin{tabular}{|c|c|c|c|c|c|}
\hline & & $\begin{array}{l}\text { Male } \\
\mathbf{N}=\mathbf{2 0}\end{array}$ & $\begin{array}{l}\text { Female } \\
\mathrm{N}=44\end{array}$ & $\chi^{2}$ & $P$ value \\
\hline SLC6A4 & LL & $50 \%$ & $27 \%$ & 2.2215 & 0.136 \\
\hline \multirow[t]{4}{*}{ 5-HTTLPR } & LS & $30 \%$ & $57 \%$ & 2.9586 & 0.085 \\
\hline & SS & $20 \%$ & $16 \%$ & 0.002 & 0.964 \\
\hline & $\mathrm{L}$ & $65 \%$ & $56 \%$ & 0.6376 & 0.425 \\
\hline & $\mathrm{S}$ & $35 \%$ & $44 \%$ & & \\
\hline HTR2A & GG & $30 \%$ & $18 \%$ & 0.5386 & 0.463 \\
\hline \multirow[t]{4}{*}{$-1438 \mathrm{G} / \mathrm{A}$} & GA & $40 \%$ & $52 \%$ & 0.4106 & 0.522 \\
\hline & AA & $30 \%$ & $30 \%$ & 0.0667 & 0.796 \\
\hline & G & $50 \%$ & $44 \%$ & 0.1652 & 0.684 \\
\hline & A & $50 \%$ & $56 \%$ & & \\
\hline BDNF & GG & $60 \%$ & $52 \%$ & 0.0929 & 0.761 \\
\hline \multirow[t]{4}{*}{ VAL66MET } & GA & $25 \%$ & $41 \%$ & 0.8996 & 0.343 \\
\hline & AA & $15 \%$ & $7 \%$ & 0.3344 & 0.563 \\
\hline & G & $73 \%$ & $73 \%$ & 0.035 & 0.852 \\
\hline & A & $28 \%$ & $27 \%$ & & \\
\hline GSK3B & $\mathrm{TT}$ & $60 \%$ & $45 \%$ & 0.6545 & 0.419 \\
\hline \multirow[t]{4}{*}{$-50 \mathrm{TC}$} & $\mathrm{TC}$ & $30 \%$ & $45 \%$ & 0.1576 & 0.691 \\
\hline & $\mathrm{CC}$ & $10 \%$ & $9 \%$ & 0.0918 & 0.762 \\
\hline & $\mathrm{T}$ & $75 \%$ & $68 \%$ & 0.3294 & 0.566 \\
\hline & $\mathrm{C}$ & $25 \%$ & $32 \%$ & & \\
\hline GSK3B & $\mathrm{TT}$ & $35 \%$ & $59 \%$ & 2.3034 & 0.129 \\
\hline \multirow[t]{4}{*}{$-157 \mathrm{TC}$} & $\mathrm{TC}$ & $55 \%$ & $30 \%$ & 2.7927 & 0.095 \\
\hline & $\mathrm{CC}$ & $10 \%$ & $11 \%$ & 0.0729 & 0.787 \\
\hline & $\mathrm{T}$ & $63 \%$ & $74 \%$ & 1.2004 & 0.273 \\
\hline & $\mathrm{C}$ & $38 \%$ & $26 \%$ & & \\
\hline
\end{tabular}

er in patient without depressive symptoms $(65 \%$ vs $12 \% ; \mathrm{P}=$ $0.0002)$. The distribution of the serotonin transporter and receptor 2A, BDNF and GSK3B polymorphisms in depressed and non-depressed CFS patients is shown in Table 5. The genotypic and allelic frequencies of the HTR2A -1438G/A polymorphism showed a difference $(\mathrm{P}=0.05)$ between the genotype AA, while no difference was observed between the frequencies of the heterozygous $\mathrm{AG}$ and homozygous $\mathrm{GG}$ genotypes. In particular, the frequency of the AA genotype was higher in the depressed patients (48\%) compared to the patients without depressive symptoms (21\%). The crude odds ratio for the presence of CFS associated with depression in subjects bearing the homozygous AA genotype was 3.56 (95\% CI, $1.13-11.17)$.

\section{Discussion}

CFS is a complex, chronic disorder of unknown aetiology, characterized by the presence of intense and disabling fa- 
Table 5. Allelic and Genotypic Distribution Between CFS Patients With and Without Depressive Symptoms

\begin{tabular}{|c|c|c|c|c|c|c|c|}
\hline & & $\begin{array}{l}\text { CFS patients with } \\
\text { depressive symptoms }\end{array}$ & $\begin{array}{l}\text { CFS patients } \\
\text { without depressive } \\
\text { symptoms }\end{array}$ & CHI & $\mathbf{P}$ & OR & $95 \% \mathrm{CI}$ \\
\hline & male & $12 \%$ & $65 \%$ & 14.3023 & 0.0002 & 0.074 & $0.0184-0.3005$ \\
\hline & female & $88 \%$ & $35 \%$ & & & 13.444 & $3.3274-54.3234$ \\
\hline \multirow[t]{5}{*}{ 5-HTTLPR } & LL & $36 \%$ & $26 \%$ & 0.2495 & 0.62 & & \\
\hline & LS & $48 \%$ & $53 \%$ & 0.0125 & 0.91 & & \\
\hline & SS & $16 \%$ & $21 \%$ & 0.0119 & 0.91 & & \\
\hline & $\mathrm{L}$ & $60 \%$ & $53 \%$ & 0.3313 & 0.56 & & \\
\hline & $\mathrm{S}$ & $40 \%$ & $47 \%$ & & & & \\
\hline HTR2A & GG & $16 \%$ & $21 \%$ & 0.0119 & 0.91 & & \\
\hline \multirow[t]{4}{*}{$-1438 \mathrm{G} / \mathrm{A}$} & GA & $36 \%$ & $59 \%$ & 2.159 & 0.14 & & \\
\hline & $\mathrm{AA}$ & $48 \%$ & $21 \%$ & 3.7822 & 0.05 & 3.56 & $1.1351-11.1675$ \\
\hline & G & $34 \%$ & $50 \%$ & 2.3891 & 0.12 & & \\
\hline & A & $66 \%$ & $50 \%$ & & & & \\
\hline BDNF & GG & $52 \%$ & $62 \%$ & 0.2337 & 0.63 & & \\
\hline \multirow[t]{4}{*}{ VAL66MET } & GA & $40 \%$ & $32 \%$ & 0.1096 & 0.74 & & \\
\hline & $\mathrm{AA}$ & $8 \%$ & $6 \%$ & 0.0417 & 0.84 & & \\
\hline & G & $72 \%$ & $78 \%$ & 0.275 & 0.60 & & \\
\hline & A & $28 \%$ & $22 \%$ & & & & \\
\hline GSK3B & TT & $40 \%$ & $44 \%$ & 0.0025 & 0.96 & & \\
\hline \multirow[t]{4}{*}{$-50 \mathrm{TC}$} & $\mathrm{TC}$ & $52 \%$ & $44 \%$ & 0.1125 & 0.74 & & \\
\hline & $\mathrm{CC}$ & $8 \%$ & $12 \%$ & 0.0002 & 0.99 & & \\
\hline & $\mathrm{T}$ & $66 \%$ & $66 \%$ & 0.0312 & 0.86 & & \\
\hline & $\mathrm{C}$ & $34 \%$ & $34 \%$ & & & & \\
\hline GSK3B & $\mathrm{TT}$ & $68 \%$ & $56 \%$ & 0.4529 & 0.50 & & \\
\hline \multirow[t]{4}{*}{$-157 \mathrm{TC}$} & $\mathrm{TC}$ & $28 \%$ & $29 \%$ & 0.0298 & 0.86 & & \\
\hline & $\mathrm{CC}$ & $4 \%$ & $15 \%$ & 0.8256 & 0.36 & & \\
\hline & $\mathrm{T}$ & $82 \%$ & $71 \%$ & 1.4555 & 0.23 & & \\
\hline & $\mathrm{C}$ & $18 \%$ & $29 \%$ & & & & \\
\hline
\end{tabular}

tigue, which interferes with daily activities, and is usually associated to systemic, physical and neuropsychological manifestations [1]. The aetiology and the pathogenic mechanisms of CFS are not fully understood; several hypotheses have been postulated [20]. One of these is the neuroendocrinological theory and an increasing amount of neuroimaging evidence supports the hypothesis that CFS patients have structural or functional abnormalities within the brain [4]. 
Genetic studies $[21,22]$ have revealed that a polymorphism in the regulatory region of SLC6A4 gene is associated with CFS. SLC6A4 govern the serotonin neuronal system and regulates the duration and strength of the interactions between serotonin and its receptors through reuptake of serotonin from the extracellular space. The polymorphisms in the 5' upstream region (5-HTTLPR) is composed of either $14(\mathrm{~S})$ or 16 (L) and, although infrequent, 18 and 20 repetitive elements (XL) [23]. In the Japanese population a significant increase of longer ( $\mathrm{L}$ and $\mathrm{XL}$ ) allelic variants was found in the CFS patients compared to the controls. The L allele is believed to retain higher transcriptional activity, which causes decreased concentration of serotonin in the extracellular space in CFS patients [23]. In Italian population we did not confirm this association; the frequency of L allele in CFS patients and controls is similar and also the distribution of the genotype in the two group is not different. It is believed that extensive molecular and anatomic diversity among serotonin receptors make the serotonergic system able to regulate pain, inflammation, memory, sleep, appetite, thermoregulation, and various neuroendocrine functions as well as depression, anxiety, and fatigue [24]. We studied a polymorphism in the promoter region, position -1438 , of serotonin receptor 2A. The $-1438 \mathrm{G} / \mathrm{A}$ polymorphism has been implicated in neuropsychiatric disorders such as schizophrenia [25] and seasonal affective disorder [26]. In our CFS population we did not found any statistical significant difference in frequencies between patients and controls. The differences between our results and those cited above may be due to ethnic genetic differences between the populations analyzed. On the basis of these results, we cannot exclude the involvement of the serotonergic system in the pathogenesis of this disease: both considered genes are presents other polymorphism that should be associated with this disease.

BDNF, a member of the growth factor family of neurotrophins, contributes to the activity-dependent synaptic development and survival of serotonergic neurons [27, 28]. The Val66Met polymorphisms analyzed in this study seems to be not associated with the disease. However BDNF it is known to have crucial roles during brain development as well as in adults brain by regulating synaptic transmission and plasticity and it regulates neuronal survival in the central nervous system via AKT pathway. Activated AKT regulates a number of cell survival-related proteins by phosphorylation, such as glycogen synthase kinase 3 beta (GSK3B) [29]. GSK3B plays a key role in the phosphorylation and regulation of metabolic enzymes and many transcription factors, and it is involved in a variety of cellular processes ranging from glycogen metabolism, insulin signaling, cell proliferation, neuronal function, oncogenesis to embryonic development. The known biochemical pathways in which GSK3B is involved, suggests a role as a susceptibility locus for multiple diseases [30]. In Italian CFS patients we do not find a significant associations with the polymorphisms (rs334558 and rs6438552) analyzed and the disease. These results do not exclude the possible role of these neurological markers in the pathophysiology of CFS.

It is possible to envisage an epigenetic interaction between genes or between these genes and environmental stressors that lead to the development of the disease. There is considerable evidence that there are complex interactions between genes, environment, that increase risk or protect against the neurobiological alterations. For example in humans the 5-HTTLPR gene and environment interaction has an effect on the vulnerability of individuals for the onset of depression in the face of stressful life events in adulthood [31]. In addiction the HPA axis has bidirectional relationships with the serotonergic and noradrenergic systems further complicating the biological picture.

Several factors have been related to the pathology of CFS, like anti-virus and autoantibodies [32], but the results from different studies are controversial and conflicting. It is therefore important to stratify the study groups in terms of symptoms, age, duration of disease, and treatments for other disorders, and to investigate gene expression.

It is firmly established that women experience of depression at roughly twice the rate of men. Contemporary research has indicated that sex hormones comprise crucial orchestrators of the differences in susceptibility associated to sex in depression, as well as in certain infectious and autoimmune diseases. Interestingly, it has been suggested that altered functioning of the immune system may be implicated in the medical morbidity of this affective disorder [33]. In our study population the $44 \%$ of the CFS patients presents depressive symptoms and the presence of female in this subgroup is significant higher $(\mathrm{P}=0.0002)$. The distribution of SLC6A4, BDNF and GSK3B polymorphisms are not different in CFS patients divided according to presence of depressive symptoms. The only difference concerns the distribution of genotypic frequencies of $-1438 \mathrm{G} / \mathrm{A}$ polymorphism in HTR2A gene. In particular, homozygous genotype AA was higher in the depressed patients compared to the patients without depressive symptoms and the crude odds ratio for the presence of CFS associated with depression in subjects bearing the homozygous AA genotype was 3.56 (95\% CI, 1.13 - 11.17). However, our sample size was appropriately powered based upon the observed frequency of the homozygous AA genotype in our control population. The -1438A/G SNP lies upstream of two alternative promoters of HTR2A and has the potential to positively modulate the HTR2A promoter in the presence of A allele in vitro [34]. Smith et al., 2008 reported that HTR2A -1438 A allele was more common in CFS subjects (48.7\%) when compared to controls $(27.4 \%)$ in American population. In addition, secondary analyses sought to evaluate quantitative measures of functional impairment, fatigue, and symptoms with HTR2A polymorphisms, revealed that the -1438 A allele was associated with a reduction in general health, vitality, and social 
function. However, examination of $-1438 \mathrm{G} / \mathrm{A}$ allelic variants revealed that the A allele creates a consensus binding site for the transcription factor Th1/E47. Whereas promoter activity was significantly greater with the A allele relative to the $\mathrm{G}$ allele it is possible to speculate that CFS patients with depressive symptoms with AA genotype have greater promoter activity of HTR2A gene. References of increased promoter activity [35], mRNA and protein levels [36] and receptor binding [37] with this promoter polymorphism and the association of the A allele with CFS sustain a hyperactive serotonergic system in the disease.

In conclusion, yet CFS remains an aetiopathogenic enigma; the neuroendocrine system remains an intriguing field of research in CFS. Globally, there is evidence for a reduced cortisol output and HPA axis hypofunction in a proportion of patients with CFS. In addition, recent insights suggest a neuroendocrine-immune interface [38-40]. Cytokines, neuropeptides, or neurotransmitters are considered to be responsible for the abnormal immune response and disrupted hypothalamo-pituitary-adrenal (HPA) axis found in the patients $[2,3]$. Furthermore, additional neuroendocrine-immune studies in humans are also require to compare CFS with mood disorders since evidence is occurring that all these condition may be characterized by inflammation.

\section{Conflict of Interest}

None.

\section{References}

1. Afari N, Buchwald D. Chronic fatigue syndrome: a review. Am J Psychiatry. 2003;160(2):221-236.

2. Parker AJ, Wessely S, Cleare AJ. The neuroendocrinology of chronic fatigue syndrome and fibromyalgia. Psychol Med. 2001;31(8):1331-1345.

3. Kuratsune H, Yamaguti K, Lindh G, Evengard B, Hagberg $\mathrm{G}$, Matsumura $\mathrm{K}$, Iwase $\mathrm{M}$, et al. Brain regions involved in fatigue sensation: reduced acetylcarnitine uptake into the brain. Neuroimage. 2002;17(3):1256-1265.

4. Chen R, Liang FX, Moriya J, Yamakawa J, Sumino H, Kanda T, Takahashi T. Chronic fatigue syndrome and the central nervous system. J Int Med Res. 2008;36(5):867874.

5. Carlo-Stella N, Badulli C, De Silvestri A, Bazzichi L, Martinetti M, Lorusso L, Bombardieri S, et al. A first study of cytokine genomic polymorphisms in CFS: Positive association of TNF-857 and IFNgamma 874 rare alleles. Clin Exp Rheumatol. 2006;24(2):179-182.

6. Lesch KP, Bengel D, Heils A, Sabol SZ, Greenberg BD, Petri S, Benjamin J, et al. Association of anxiety-related traits with a polymorphism in the serotonin transporter gene regulatory region. Science. 1996;274(5292):15271531.

7. Chee IS, Lee SW, Kim JL, Wang SK, Shin YO, Shin SC, Lee $\mathrm{YH}$, et al. 5-HT2A receptor gene promoter polymorphism $-1438 \mathrm{~A} / \mathrm{G}$ and bipolar disorder. Psychiatr Genet. 2001;11(3):111-114.

8. Choi MJ, Lee HJ, Ham BJ, Cha JH, Ryu SH, Lee MS. Association between major depressive disorder and the $-1438 \mathrm{~A} / \mathrm{G}$ polymorphism of the serotonin $2 \mathrm{~A}$ receptor gene. Neuropsychobiology. 2004;49(1):38-41.

9. Castren E, Rantamaki T. Role of brain-derived neurotrophic factor in the aetiology of depression: implications for pharmacological treatment. CNS Drugs. 2010;24(1):1-7.

10. Greenberg ME, Xu B, Lu B, Hempstead BL. New insights in the biology of BDNF synthesis and release: implications in CNS function. J Neurosci. 2009;29(41):1276412767.

11. Bath KG, Lee FS. Variant BDNF (Val66Met) impact on brain structure and function. Cogn Affect Behav Neurosci. 2006;6(1):79-85.

12. Jope RS, Roh MS. Glycogen synthase kinase-3 (GSK3) in psychiatric diseases and therapeutic interventions. Curr Drug Targets. 2006;7(11):1421-1434.

13. Mazanetz MP, Fischer PM. Untangling tau hyperphosphorylation in drug design for neurodegenerative diseases. Nat Rev Drug Discov. 2007;6(6):464-479.

14. Kwok JB, Hallupp M, Loy CT, Chan DK, Woo J, Mellick GD, Buchanan DD, et al. GSK3B polymorphisms alter transcription and splicing in Parkinson's disease. Ann Neurol. 2005;58(6):829-839.

15. Carlo-Stella N, Cuccia M. Demographic and clinical aspects of an Italian patient population with chronic fatigue syndrome. Reumatismo. 2009;61(4):285-289.

16. Jason LA, Richman JA, Rademaker AW, Jordan KM, Plioplys AV, Taylor RR, McCready W, et al. A community-based study of chronic fatigue syndrome. Arch Intern Med. 1999;159(18):2129-2137.

17. Lloyd AR, Hickie I, Boughton CR, Spencer O, Wakefield D. Prevalence of chronic fatigue syndrome in an Australian population. Med J Aust. 1990;153(9):522528.

18. Kim $\mathrm{CH}$, Shin HC, Won CW. Prevalence of chronic fatigue and chronic fatigue syndrome in Korea: community-based primary care study. J Korean Med Sci. 2005;20(4):529-534.

19. Wessely S, Chalder T, Hirsch S, Wallace P, Wright D. The prevalence and morbidity of chronic fatigue and chronic fatigue syndrome: a prospective primary care study. Am J Public Health. 1997;87(9):1449-1455.

20. Working Group of the Royal Australasian College of P. Chronic fatigue syndrome. Clinical practice guidelines--2002. Med J Aust. 2002;176 Suppl:S23-56.

21. Narita N, Narita M, Takashima S, Nakayama M, Nagai 
T, Okado N. Serotonin transporter gene variation is a risk factor for sudden infant death syndrome in the Japanese population. Pediatrics. 2001;107(4):690-692.

22. Smith AK, Dimulescu I, Falkenberg VR, Narasimhan S, Heim C, Vernon SD, Rajeevan MS. Genetic evaluation of the serotonergic system in chronic fatigue syndrome. Psychoneuroendocrinology. 2008;33(2):188-197.

23. Narita M, Nishigami N, Narita N, Yamaguti K, Okado N, Watanabe Y, Kuratsune H. Association between serotonin transporter gene polymorphism and chronic fatigue syndrome. Biochem Biophys Res Commun. 2003;311(2):264-266.

24. Raymond JR, Mukhin YV, Gelasco A, Turner J, Collinsworth G, Gettys TW, Grewal JS, et al. Multiplicity of mechanisms of serotonin receptor signal transduction. Pharmacol Ther. 2001;92(2-3):179-212.

25. Arranz MJ, Munro J, Owen MJ, Spurlock G, Sham PC, Zhao J, Kirov G, et al. Evidence for association between polymorphisms in the promoter and coding regions of the 5-HT2A receptor gene and response to clozapine. Mol Psychiatry. 1998;3(1):61-66.

26. Enoch MA, Goldman D, Barnett R, Sher L, Mazzanti CM, Rosenthal NE. Association between seasonal affective disorder and the 5-HT2A promoter polymorphism, -1438G/A. Mol Psychiatry. 1999;4(1):89-92.

27. Bozzini S, Gambelli P, Boiocchi C, Schirinzi S, Falcone R, Buzzi P, Storti C, et al. Coronary artery disease and depression: possible role of brain-derived neurotrophic factor and serotonin transporter gene polymorphisms. Int J Mol Med. 2009;24(6):813-818.

28. Huang EJ, Reichardt LF. Neurotrophins: roles in neuronal development and function. Annu Rev Neurosci. 2001;24:677-736.

29. Jope RS, Johnson GV. The glamour and gloom of glycogen synthase kinase-3. Trends Biochem Sci. 2004;29(2):95-102.

30. Lucas JJ, Hernandez F, Gomez-Ramos P, Moran MA, Hen R, Avila J. Decreased nuclear beta-catenin, tau hyperphosphorylation and neurodegeneration in GSK3beta conditional transgenic mice. EMBO J. 2001;20(12):27-39.

31. Brown GW, Harris TO. Depression and the serotonin transporter 5-HTTLPR polymorphism: a review and a hypothesis concerning gene-environment interaction. J Affect Disord. 2008;111(1):1-12.

32. Ortega-Hernandez OD, Cuccia M, Bozzini S, Bassi N, Moscavitch S, Diaz-Gallo LM, Blank M, et al. Autoantibodies, polymorphisms in the serotonin pathway, and human leukocyte antigen class II alleles in chronic fatigue syndrome: are they associated with age at onset and specific symptoms? Ann N Y Acad Sci. 2009;1173:589599.

33. Pitychoutis PM, Papadopoulou-Daifoti Z. Of depression and immunity: does sex matter? Int J Neuropsychopharmacol. 2010;13(5):675-689.

34. Parsons MJ, D’Souza UM, Arranz MJ, Kerwin RW, Makoff AJ. The -1438A/G polymorphism in the 5-hydroxytryptamine type $2 \mathrm{~A}$ receptor gene affects promoter activity. Biol Psychiatry. 2004;56(6):406-410.

35. Polesskaya OO, Sokolov BP. Differential expression of the " $C$ " and "T" alleles of the 5-HT2A receptor gene in the temporal cortex of normal individuals and schizophrenics. J Neurosci Res. 2002;67(6):812-822.

36. Turecki G, Briere R, Dewar K, Antonetti T, Lesage AD, Seguin M, Chawky N, et al. Prediction of level of serotonin $2 \mathrm{~A}$ receptor binding by serotonin receptor $2 \mathrm{~A}$ genetic variation in postmortem brain samples from subjects who did or did not commit suicide. Am J Psychiatry. 1999;156(9):1456-1458.

37. Cleare AJ, Bearn J, Allain T, McGregor A, Wessely S, Murray RM, O'Keane V. Contrasting neuroendocrine responses in depression and chronic fatigue syndrome. J Affect Disord. 1995;34(4):283-289.

38. Miller GE, Chen E, Sze J, Marin T, Arevalo JM, Doll R, $\mathrm{Ma} \mathrm{R}$, et al. A functional genomic fingerprint of chronic stress in humans: blunted glucocorticoid and increased NF-kappaB signaling. Biol Psychiatry. 2008;64(4):266272.

39. Miller AH. Inflammation versus glucocorticoids as purveyors of pathology during stress: have we reached the tipping point? Biol Psychiatry. 2008;64(4):263-265.

40. Heijnen CJ. Receptor regulation in neuroendocrineimmune communication: current knowledge and future perspectives. Brain Behav Immun. 2007;21(1):1-8. 